\title{
FDI in Retail Sector in India-Conceptual, Descriptive and Analytical Study
}

\author{
Dr. G.1.Parvathamma, \\ Associate professor, Department of Economics Bangalore UniversityP.G.Centre, Kolar
}

\begin{abstract}
Retailing in India is one of the pillars of its economy and accounts for 14 to 15 percent of its GDP. The Indian retail market is estimated to be US\$ 500 billion and one of the top five retail markets in the world by economic value. India is one of the fastest growing retail markets in the world, with 1.2 billion people. As of 2013, India's retailing industry was essentially owner manned small shops. In 2010, larger format convenience stores and supermarkets accounted for about 4 percent of the industry, and these were present only in large urban centers. India's retail and logistics industry employs about 40 million Indians (3.3 percent of Indian population). Indian market has high complexities in terms of a wide geographic spread and distinct consumer preferences varying by each region necessitating a need for localization even within the geographic zones. India has highest number of outlets per person (7 per thousand) Indian retail space per capita at 2 sq ft $\left(0.19 \mathrm{~m}^{2}\right) /$ person is lowest in the world Indian retail density of 6 percent is highest in the world. 1.8 million Households in India have an annual income of over $\mathbf{\mathbf { 2 }} 4.5$ million (US\$74,700.00). A number of merger and acquisitions have begun in Indian retail market. PWC estimates the multi-brand retail market to grow to $\$ 220$ billion by 2020. A growing and mushrooming retail sector means that its contribution to GDP would grow. It would thus help in expanding the economy, generate employment and result in more tax income. The present study made an attempt to highlights the importance of FDI in retail sector; analyze the structure of retail industry group and its market reach in India, Assess the FDI on various sectors related to the retail sector. Analyze the growth performance of retail industry over a period of time and examine the Indian retail reforms and provide some suggestions to protect and promote the interest of small, unorganized retailers and farmers in the country.
\end{abstract}

Keywords: FDI, Retail sector, whole sale sector, GDP

\section{Introduction}

The Foreign Direct Investment means "cross border investment made by a resident in one economy in an enterprise in another economy, with the objective of establishing a lasting interest in the investee economy. FDI is also described as "investment into the business of a country by a company in another country". Mostly the investment is into production by either buying a company in the target country or by expanding operations of an existing business in that country". Such investments can take place for many reasons, including to take advantage of cheaper wages, special investment privileges (e.g. tax exemptions) offered by the country. Countries Seek FDI for the purpose of three (a) Domestic capital is inadequate for purpose of economic growth;(b) Foreign capital is usually essential, at least as a temporary measure, during the period when the capital market is in the process of development;(c) Foreign capital usually brings it with other scarce productive factors like technical knowhow, business expertise and knowledge. An Indian company may receive Foreign Direct Investment under the two routes as given under. Automatic Route;FDI is allowed under the automatic route without prior approval either of the Government or the Reserve Bank of India in all activities/sectors as specified in the consolidated FDI Policy, issued by the Government of India from time to time.

ii. Government Route;FDI in activities not covered under the automatic route requires prior approval of the Government which are considered by the Foreign Investment Promotion Board (FIPB), Department of Economic Affairs, Ministry of Finance. FDI is prohibited under the Government Route as well as the Automatic Route in the following sectors) Atomic Energy,ii) Lottery Business,iii) Gambling and Betting,iv) Business of Chit Fund v) Nidhi Company,vi) Agricultural (excluding Floriculture, Horticulture, Development of seeds, Animal Husbandry, Pisciculture and cultivation of vegetables, mushrooms, etc. under controlled conditions and services related to agro and allied sectors) and Plantations activities (other than Tea Plantations),vii) Housing and Real Estate business (except development of townships, construction of residential/commercial premises, roads or bridges to the extent specified in notification,viii) Trading in Transferable Development Rights (TDRs).ix) Manufacture of cigars, cheroots, cigarillos and cigarettes, of tobacco or of tobacco substitutes. 
Retailing in India is one of the pillars of its economy and accounts for 14 to 15 percent of its GDP. The Indian retail market is estimated to be US\$ 500 billion and one of the top five retail markets in the world by economic value. India is one of the fastest growing retail markets in the world, with 1.2 billion people. As of 2013, India's retailing industry was essentially owner manned small shops. In 2010, larger format convenience stores and supermarkets accounted for about 4 percent of the industry, and these were present only in large urban centers. India's retail and logistics industry employs about 40 million Indians (3.3 percent of Indian population). Indian market has high complexities in terms of a wide geographic spread and distinct consumer preferences varying by each region necessitating a need for localization even within the geographic zones. India has highest number of outlets per person (7 per thousand) Indian retail space per capita at $2 \mathrm{sq} \mathrm{ft}(0.19 \mathrm{~m} 2) /$ person is lowest in the world Indian retail density of 6 percent is highest in the world. 1.8 million Households in India have an annual income of over $\mathbf{\mathbf { S }} 4.5$ million (US\$74,700.00). A number of merger and acquisitions have begun in Indian retail market. PWC estimates the multi-brand retail market to grow to $\$ 220$ billion by 2020 . A growing and mushrooming retail sector means that its contribution to GDP would grow. It would thus help in expanding the economy, generate employment and result in more tax income

The recent approval by the Union Cabinet for allowing 51\% foreign direct investment (FDI) in multibrand retail in India and increasing the FDI limit in single brand retail in India to 100\% (from the existing 51\%) has come at a time when global retailers are facing headwinds in their home countries and thus scouting for new emerging markets, while domestic players, on the other hand, are burdened with piling debt. While this long awaited approval, which has come as a relief to many organized retailers, includes a set of riders for the foreign investors like minimum investment, deployment of funds invested, local sourcing, cities being opened for initial roll-out, etc. Also, opposition from certain State Governments and political parties raises significant hurdles for effective implementation of the reforms. FDI in multi-brand retail has been opposed by several in the past citing fears of loss of employment and that traditional retail may be affected. However, adherents of the same indicate easy access to capital for domestic retailers, increased transfer of technology, enhanced supply chain efficiencies, increased employment opportunities and curtailment of inflation as the perceived benefits. While this long awaited move is not expected to have an immediate impact on the Indian retail sector, it is expected to reap benefits in the medium to long-term. However, the move needs to be monitored in the wake of the current opposition by several political parties, which if persists, may pose a major roadblock in the entry of the foreign retailers in India. Besides restricting the number of cities these retailers can operate in, it could also lead to problems in creating supply chain efficiency. For the domestic retailers, reforms at structural level would be required for partnering with foreign companies for the purpose of entering the states where FDI will be encouraged. At the same time, local retailers (kirana stores) are expected to remain a key element in the ecosystem in the foreseeable future, with their ability to offer door step service and convenient access.

\section{Background}

In 1997, the Indian retail sector witnessed the first footprints of FDI with 100\% FDI being permitted in cash \& carry wholesale trading under the government approval route, subsequently brought under the automatic route in 2006. As a step ahead, FDI in single brand retail was permitted to the extent of $51 \%$ in 2006, while FDI in multi-brand retail remained prohibited till recently. In July 2010, the Department of Industrial Policy and Promotion (DIPP) had put up a discussion paper proposing FDI in multi-brand retail. In July 2011, a Committee of Secretaries (CoS) had cleared the proposal to allow up to 51\% FDI in multi-brand retail, which has been approved by the Union Cabinet in November 2011, albeit with a few riders. The Union Cabinet has also approved increasing the FDI limit in single brand retail to $100 \%$ with government approval. While no parliamentary approval is needed for the decision, State Governments have the prerogative to disallow the same in their respective states. Mounting opposition by several political parties and State Governments has raised hurdles in the effective implementation of the key reform measure.

Until 2011, Indian central government denied foreign direct investment (FDI) in multi-brand retail, forbidding foreign groups from any ownership in supermarkets, convenience stores or any retail outlets. Even single-brand retail was limited to $51 \%$ ownership and a bureaucratic process. In November 2011, India's central government announced retail reforms for both multi-brand stores and single-brand stores. These market reforms paved the way for retail innovation and competition with multi-brand retailers such as Walmart,Carrefour and Tesco, as well single brand majors such as IKEA, Nike, and Apple. The announcement sparked intense activism, both in opposition and in support of the reforms. In December 2011, under pressure from the opposition, Indian government placed the retail reforms on hold till it reaches a consensus.

In January 2012, India approved reforms for single-brand stores welcoming anyone in the world to innovate in Indian retail market with $100 \%$ ownership, but imposed the requirement that the single brand retailer source 30 percent of its goods from India. Indian government continues the hold on retail reforms for multibrand stores. In June 2012, IKEA announced it had applied for permission to invest $\$ 1.9$ billion in India and set 
up 25 retail stores. An analyst from Fitch Group stated that the 30 percent requirement was likely to significantly delay if not prevent most single brand majors from Europe, USA and Japan from opening stores and creating associated jobs in India. On 14 September 2012, the government of India announced the opening of FDI in multi-brand retail, subject to approvals by individual states. This decision was welcomed by economists. and the markets, but caused protests and an upheaval in India's central government's political coalition structure. On 20 September 2012, the Government of India formally notified the FDI reforms for single and multi brand retail, thereby making it effective under Indian law. On 7 December 2012, the Federal Government of India allowed 51\% FDI in multi-brand retail in India. The government managed to get the approval of multibrand retail in the parliament despite heavy uproar from the opposition (the NDA and leftist parties). Some states will allow foreign supermarkets likeWalmart, Tesco and Carrefour to open while other states will not.

\section{Objectives}

1) To analyze the structure of retail industry group and its market reach in India

2. To assess the FDI on various sectors related to the retail sector.

3 , To analyze the growth performance of retail industry over a period of time

4. To examine the Indian retail reforms and to provide some suggestions to protect and promote the interest of small, unorganized retailers and farmers in the country.

\section{Research Methodology}

The researcher have adopted analytical, descriptive and comparative methodology for this study .Reliance has been placed on secondary data sources such as books, journals, newspapers and online database .However, the interpretation of the data and suggestions made assume importance for the healthy growth of the retail sector in the country.

Table-1, Top 5 Countries for FDI since 2000-2010:

\begin{tabular}{|l|l|l|}
\hline country & Inflow in \% age terms & Inflow in absolute terms(millions US dollars) \\
\hline Mauritius & $42 \%$ & 50164 \\
\hline USA & 7 & 8914 \\
\hline Singapore & 9 & 11275 \\
\hline UK & 5 & 6158 \\
\hline Netherlands & 4 & 4968 \\
\hline
\end{tabular}

Majority of the foreign direct investment comes through Mauritius as it enjoys several tax advantages, which works well for the international investors.

\section{Indian Retailers}

A 2012 PWC report states that modern retailing has a 5\% market share in India with about \$27 billion in sales, and is growing at 15 to $20 \%$ per year. There are many modern retail format and mall companies in India. Some examples are in the following table 2.

Table-2, shows Indian retail group and market reach

\begin{tabular}{|l|l|}
\hline Indian Retail Group & Market Reach in 2011 and Notes \\
\hline Pantaloon Retail & 65 stores and 21 factory outlets in 35 cities, 2 million square feet space \\
\hline Shoppers Stop & 51 stores in 23 cities, 3.2 million square feet space \\
\hline Spencers Retail & 200 stores in 45 cities, 1 million square feet space \\
\hline Reliance Retail & 708 mart and supermarkets, 20 wholesale stores in 15 cities, 508 fashion and lifestyle \\
\hline Bharti Retail & 74 Easyday stores, plans to add 10 million square feet by 2017 \\
\hline Birla More & 575 stores nationwide \\
\hline Tata Trent & 59 Westside mall stores, 13 hypermarkets \\
\hline Lifestyle Retail & 15 lifestyle stores, 8 home centers \\
\hline Future Group & 193 stores in 3 cities, one of three largest supermarkets retailer in India by sales $\mathbf{K}$ \\
\hline
\end{tabular}

\section{FDI In Different Sectors}

\section{(a) $26 \%$ FDI is permitted in}

Defence (In July 2013, there has been no change in FDI limit but higher investment may be considered in state of the art technology production by CCS), (2) Pension sector (allowed in October 2012 as per 
cabinet decision), (3) Newspaper and media,(4) Courier Services (through automatic route)(5)Tea Plantation (upto $49 \%$ through automatic route; $49-100 \%$ through FIPB route)

\section{(b) $49 \%$ FDI is permitted in:}

Banking, Cablenetnetwork,DTH,Infrastructureinvestment,TelecomInsurance (in July 2013 it was raised to $49 \%$ from $26 \%$ subject to Parliament approval),Petroleum Refining (49\% allowed under automatic route),Power Exchanges (49\% allowed under automatic route),Stock Exchanges, Depositories allowed under automatic route upto $49 \%, 49 \%$ (FDI \& FII) in power exchanges registered under the Central Electricity Regulatory Commission (Power Market) Regulations 2010 subject to an FDI limit of 26 per cent and an FII limit of 23 per cent of the paid-up capital is now permissible. [Permitted in September 2012]

\section{(c) $\mathbf{5 1 \%}$ is permitted in Multi-Brand Retail (Since September 2012)}

Petro-pipelines

\section{(d) $74 \%$ FDI is permitted in}

Atomic minerals, Science Magazines/Journals, Petro marketing Coal and Lignite mines, Credit information companies (rose from $49 \%$ to $74 \%$ in July, 2013)

\section{(e) $100 \%$ FDI is permitted in}

Single Brand Retail (100\% FDI allowed in single brand retail; 49\% through automatic route; $49-100 \%$ through FIPB).In the following sectors $100 \%$ FDI is permitted.

Advertisement, Airports, cold-storage, BPO/Call centers, E-commerce, Energy (except atomic),export trading house,

Films,Hotel,tourismMetro-train,Mines(gold,silver),Petroleumexploration,

Pharmaceuticals

Pollutioncontrol ,Postalservice,Roads,highways,ports, Township,wholesale trading

Telecom (raised from $74 \%$ to $100 \%$ in July, 2013 by GoI)

Asset Reconstruction Companies (increased from $74 \%$ to 100 in July, 2013. Out of this upto $49 \%$ will be under automatic route)

Source: RBI website, Newpaper reports, GoI data

As part of the economic liberalization process set in place by the Industrial Policy of 1991, the Indian government has opened the retail sector to FDI slowly through a series of steps:

In 1995. World Trade Organizations' (WTO) General Agreement on Trade in Services, which includes both wholesale and retailing services, came into effect. In 1997 FDI in cash and carry (wholesale) with $100 \%$ rights allowed under the government approval route; In 2006: FDI in cash and carry (wholesale) was brought under automatic approval route; Up to $51 \%$ investment in single brand retail outlet permitted, subject to Press Note 3 (2006 series)2011 : 100\% FDI in Single Brand Retail allowed' and 2012, On Sept. 13, Government approved the allowance of 51 percent foreign investment in multi-brand retail, [It also relaxed FDI norms for civil aviation and broadcasting sectors]'

Table-3, Modern retail by different countries.

Source: RBI website, Newpaper reports, GoI data

\begin{tabular}{|l|l|}
\hline Country & $\begin{array}{l}\text { Modern Retai } \\
\text { (in 2011, \% of total) }\end{array}$ \\
\hline India & $7 \%$ \\
\hline China & $20 \%$ \\
\hline Thailand & $40 \%$ \\
\hline United States & $85 \%$ \\
\hline
\end{tabular}

INDIAN REATAIL REFORMS

Until 2011, Indian central government denied foreign direct investment (FDI) in multi-brand Indian retail, forbidding foreign groups from any ownership in supermarkets, convenience stores or any retail outlets, to sell multiple products from different brands directly to Indian consumers. reforms.

The government of Manmohan Singh, prime minister, announced on 24 November 2011 the following

India will allow foreign groups to own up to 51 per cent in "multi-brand retailers", as supermarkets are known in India, in the most radical pro-liberalisation reform passed by an Indian cabinet in years; single brand retailers, 
such as Apple and IKEA, can own 100 percent of their Indian stores, up from the previous cap of 51 percent; both multi-brand and single brand stores in India will have to source nearly a third of their goods from small and medium-sized Indian suppliers; all multi-brand and single brand stores in India must confine their operations to 53-odd cities with a population over one million, out of some 7935 towns and cities in India. It is expected that these stores will now have full access to over 200 million urban consumers in India;

multi-brand retailers must have a minimum investment of US\$100 million with at least half of the amount invested in back end infrastructure, including cold chains, refrigeration, transportation, packing, sorting and processing to considerably reduce the post harvest losses and bring remunerative prices to farmers; the opening of retail competition will be within India's federal structure of government. In other words, the policy is an enabling legal framework for India. The states of India have the prerogative to accept it and implement it, or they can decide to not implement it if they so choose. Actual implementation of policy will be within the parameters of state laws and regulations.

The opening of retail industry to global competition is expected to spur a retail rush to India. It has the potential to transform not only the retailing landscape but also the nation's ailing infrastructure. A Wall Street Journal article claims that fresh investments in Indian organized retail will generate 10 million new jobs between 2012-2014, and about five to six million of them in logistics alone; even though the retail market is being opened to just 53 cities out of about 8000 towns and cities in India. In 11 January 2012, India approved increased competition and innovation in single-brand retail. The reform seeks to attract investments in operations and marketing, improve the availability of goods for the consumer, encourage increased sourcing of goods from India, and enhance competitiveness of Indian enterprises through access to global designs, technologies and management practices. In this announcement, India requires single-brand retailer, with greater than $51 \%$ foreign ownership, to source at least $30 \%$ of the value of products from Indian small industries, village and cottage industries, artisans and craftsmen.

\section{Growth Over 1997-2010}

India in 1997 allowed foreign direct investment (FDI) in cash and carry wholesale. Then, it required government approval. The approval requirement was relaxed, and automatic permission was granted in 2006. Between 2000 to 2010, Indian retail attracted about $\$ 1.8$ billion in foreign direct investment, representing a very small 1.5\% of total investment flow into India. Single brand retailing attracted 94 proposals between 2006 and 2010, of which 57 were approved and implemented. For a country of 1.2 billion people, this is a very small number. Some claim one of the primary restraints inhibiting better participation was that India required single brand retailers to limit their ownership in Indian outlets to $51 \%$. China in contrast allows $100 \%$ ownership by foreign companies in both single brand and multi-brand retail presence. Indian retail has experienced limited growth, and its spoilage of food harvest is amongst the highest in the world, because of very limited integrated cold-chain and other infrastructure. India has only 5386 stand-alone cold storages, having a total capacity of 23.6 million metric tons. However, 80 percent of this storage is used only for potatoes. The remaining infrastructure capacity is less than $1 \%$ of the annual farm output of India and grossly inadequate during peak harvest seasons. This leads to about $30 \%$ losses in certain perishable agricultural output in India, on average, every year.

Indian laws already allow foreign direct investment in cold-chain infrastructure to the extent of 100 percent. There has been no interest in foreign direct investment in cold storage infrastructure build out. Experts claim that cold storage infrastructure will become economically viable only when there is strong and contractually binding demand from organized retail. The risk of cold storing perishable food, without an assured way to move and sell it, puts the economic viability of expensive cold storage in doubt. In the absence of organized retail competition and with a ban on foreign direct investment in multi-brand retailers, foreign direct investments are unlikely to begin in cold storage and farm logistics infrastructure. Until 2010, intermediaries and middlemen in India have dominated the value chain. Due to a number of intermediaries involved in the traditional Indian retail chain, norms are flouted and pricing lacks transparency. Small Indian farmers realize only $1 / 3$ rd of the total price paid by the final Indian consumer, as against $2 / 3$ rd by farmers in nations with a higher share of organized retail The $60 \%+$ margins for middlemen and traditional retail shops have limited growth and prevented innovation in Indian retail industry.

India has had years of debate and discussions on the risks and prudence of allowing innovation and competition within its retail industry. Numerous economists repeatedly recommended to the Government of India that legal restrictions on organized retail must be removed, and the retail industry in India must be opened to competition. For example, in an invited address to the Indian parliament in December 2010, Jagdish Bhagwati, Professor of Economics and Law at the Columbia University analysed the relationship between growth and poverty reduction, then urged the Indian parliament to extend economic reforms by freeing up of the retail sector, further liberalization of trade in all sectors, and introducing labor market reforms. Such reforms Professor Bhagwati argued will accelerate economic growth and make a sustainable difference in the life of 
India's poorest.A 2007 report noted that an increasing number of people in India are turning to the services sector for employment due to the relative low compensation offered by the traditional agriculture and manufacturing sectors. The organized retail market is growing at 35 percent annually while growth of unorganized retail sector is pegged at 6 percent. The Retail Business in India is currently at the point of inflection. As of 2008, rapid change with investments to the tune of US\$25 billion was being planned by several Indian and multinational companies in the next 5 years. It is a huge industry in terms of size and according to India Brand Equity Foundation (IBEF), it is valued at about US\$395.96 billion. Organised retail is expected to garner about 16-18 percent of the total retail market (US\$65-75 billion) in the next 5 years. India has topped the A.T. Kearney's annual Global Retail Development Index (GRDI) for the third consecutive year, maintaining its position as the most attractive market for retail investment. The Indian economy has registered a growth of $8 \%$ for 2007 . The predictions for 2008 are $7.9 \%$. The enormous growth of the retail industry has created a huge demand for real estate. Property developers are creating retail real estate at an aggressive pace and by 2010, 300 malls are estimated to be operational in the country.

\section{Growth After 2011}

Before 2011, India had prevented innovation and organized competition in its consumer retail industry. Several studies claim that the lack of infrastructure and competitive retail industry is a key cause of India's persistently high inflation. Furthermore, because of unorganized retail, in a nation where malnutrition remains a serious problem, food waste is rife. Well over $30 \%$ of food staples and perishable goods produced in India spoil because poor infrastructure and small retail outlets prevent hygienic storage and movement of the goods from the farmer to the consumer. One report estimates the 2011 Indian retail market as generating sales of about $\$ 470$ billion a year, of which a minuscule $\$ 27$ billion comes from organized retail such as supermarkets, chain stores with centralized operations and shops in malls. The opening of retail industry to free market competition, some claim will enable rapid growth in retail sector of Indian economy. Others believe the growth of Indian retail industry will take time, with organized retail possibly needing a decade to grow to a $25 \%$ share. A $25 \%$ market share, given the expected growth of Indian retail industry through 2021, is estimated to be over $\$ 250$ billion a year: a revenue equal to the 2009 revenue share from Japan for the world's 250 largest retailers.,

The Economist forecasts that Indian retail will nearly double in economic value, expanding by about $\$ 400$ billion by 2020.The projected increase alone is equivalent to the current retail market size of France.In 2011, food accounted for $70 \%$ of Indian retail, but was under-represented by organized retail. A.T. Kearney estimates India's organized retail had a $31 \%$ share in clothing and apparel, while the home supplies retail was growing between $20 \%$ to $30 \%$ per year. These data correspond to retail prospects prior to November announcement of the retail reform. It might be true that India has the largest number of shops per inhabitant. However there are detailed figures for Belgium, the Netherlands and Luxemburg. In Belgium, the number of outlets is approximately 8 per 1,000 and in the Netherlands it is 6 . So the Indian number must be far higher.

\section{Advantages Of The Fdi In Retail Secotr}

India is a developing nation and like any developing business the Indian market also needs lots of investment for the growth of the country. It is necessary to allow FDI in a developingcountrylikeIndiaforthefollowingreasons.

1. Helps in attaining high GDP growth rate and Stable economy.2. Low inflation. (Inflation came down from $17 \%$ to $7 \%$ in 95).3.Helps in Access to the advance technology of the world. Management skills, intellectual property and creating world class infrastructure.4. Better utilization of resources 5. Helps in increasing exports and tax revenue, Good foreign exchange earnings and increases the employment 6 . Increase in the no. of trained labours.9. Help in capital formation by bringing fresh Capital and Increases competition within the local market and this brings higher efficiencies.

\section{Suggestion}

FDI should be allowed in retail sector, but the government should frame the policies which help in boosting the domestic manufacturing .More over there should be restriction in repatriation of profits, so that there should be stability in the value of Indian rupee. The government should establish a regulatory authority which will keep a check on these companies, so that these companies will not take undue advantage from farmers and does not involve in malpractice. FDI in India should be allowed but there should be some strict rules and policies to control the level of involvement of FDI in Indian market. It should be allowed partially not $100 \%$. In every field it has its pros and cons,Eg. If we talk about FDI in retail sector then it has various advantages and disadvantages too Advantages are - it will provide better infrastructure. Better quality of product. Inflation rate will decrease. It will boost the economy and will increase the GDP of our nation. Disadvantages - it will affect small scale businessmen. Unemployment will increase etc. 


\section{Conclusions}

India is a developing country. introducing FDI in retail sector would sure boost the economy for years ahead, not to mention the other added benefits like lower prices of commodities for consumers, better quality products, employments, etc. These benefits cannot be achieved from investments within the country, for one we are not capable of such huge and long term investments. We cannot even compete with foreign companies in providing all such benefits in such low margins. Opening up of FDI in multi-brand retail in India could potentially be a mixed blessing for domestic players. While initially the small indigenous retailers' business would be impacted once modern retail enters the locality, this adverse impact is expected to be short-lived and to weaken over time. While this long awaited move is not expected to have an immediate impact on the Indian retail sector, it is expected to reap benefits in the medium to long-term as it will help improve the a) balance sheet and liquidity profile of cash-starved retailers with aggressive expansion plans b) supply chain and backend infrastructure while reducing margins for middlemen through direct sourcing from farmers and c) arrest inflationary pressures through increased supplies facilitated by improved productivity of farmers and reduction of agri-waste. However, once $100 \%$ FDI is allowed in retail that is when the landscape will become extremely competitive. Further, the move needs to be monitored in the wake of the current opposition by several political parties. At last conclude that FDI should be allowed for small period of time with strict rules and policies

\section{References}

[1]. Anand Dikshit (12 August 2011). "The Uneasy Compromise - Indian Retail". The Wall Street Journal.

[2]. "Winning the Indian consumer". McKinsey \& Company. 2005.

[3]. Majumder, Sanjoy (25 November 2011). "Changing the way Indians shop". BBC News.

[4]. http://www.indianexpress.com/news/fe-campus-mastermind-response-by-mahavir-accha-to-question-for-jan-713/1057932/

[5]. "Retailing in India Unshackling the chain stores".The Economist. 29 May 2008

[6]. ^Jump up to:a b Agarwal, Vibhuti; Bahree, Megha (7 December 2011)."India puts retails reforms on hold". The Wall Street Journal.

[7]. Sharma, Amol; Sahu, Prasanta (11 January 2012). "India Lifts Some Limits on Foreign Retailers". The Wall Street Journal.

[8]. Amol Sharma (24 June 2012). "IKEA Knocks on India's Door". The Wall Street Journal.

[9]. ^ Jump up to:a b "Ikea shelves Indian retail market move". The Financial Times. 22 January 2012.

[10]. "Department of Industrial Policy \& Promotion (FC-I Section), Press Note No.5 (2012 Series) - multi-brand retail". Ministry of Commerce \& Industry, Government of India. 20 September 2012.

[11]. "FDI in multi-brand retail comes into effect; way clear for Walmart". The Economic Times. 20 September 2012.

[12]. Jump up to:a b c "SMEs welcome FDI in retail". CIOL. 6 December 2012. Retrieved 28 February 2013.

[13]. http://dipp.nic.in/DiscussionPapers/DP_FDI_MultiBrandRetailTrading_06July 2010.pdf 4. India's Retail Sector (Dec 21, 2010)

[14]. http://www.cci.in/pdf/surveys_reports/indias_retail_sector.pdf

[15]. http://www.eastasiaforum.org/2010/12/24/indias-fdi-policiesparadigm-shift/

[16]. http://www.eastasiaforum.org/2010/12/24/indias-fdi-policiesparadigm-shift/

[17]. http://pepsicoindia.co.in/purpose/environmentalsustainability/Partnership-with-farmers.html 